Check for updates

Cite this: RSC Adv., 2018, 8, 1039

Received 29th September 2017 Accepted 17th December 2017

DOI: 10.1039/c7ra10765j

rsc.li/rsc-advances

\section{Evaluation and optimization of a new microbial enhancement plug-flow ditch system for the pretreatment of acid mine drainage: semi-pilot test}

\author{
Yongwei Song, (D) *a Heru Wang, ${ }^{a}$ Jun Yang, ${ }^{a}$ Lixiang Zhou, ${ }^{b}$ Jingcheng Zhou ${ }^{a}$ \\ and Yanxiao $\mathrm{Cao}^{\mathrm{a}}$
}

Acid mine drainage (AMD) is typically characterized by low $\mathrm{pH}$, a high concentration of sulfate and dissolved heavy metals. Therefore, it is of practical significance to promote the transformation of soluble Fe and $\mathrm{SO}_{4}{ }^{2-}$ into iron hydroxysulfate minerals by biomineralization of Acidithiobacillus ferrooxidans. This enhances the lime neutralization efficiency of AMD by reducing the production of ferric hydroxide and waste gypsum. In this study, a new microbial enhanced plug-flow ditch reaction system was developed for the pretreatment of AMD on a semi-pilot scale. System stability under different hydraulic retention times (HRTs) was examined and the effects of microbe enhancement-lime neutralization technology and direct lime neutralization technology were compared. The bio-oxidation efficiency of $\mathrm{Fe}^{2+}\left(5 \mathrm{~g} \mathrm{~L}^{-1}\right)$ reached $100 \%$ in some parts of the system when HRT was 3 and 2 days, and the time taken to reach steady state was 6 and 4 days, respectively. When the HRT was 1 day, the reaction system had operated for 4 days before the equilibrium was lost. At the optimum HRT ( 2 days) and after the system was stable, the average precipitation rate of total Fe was $53.62 \%$ and the average removal rate of $\mathrm{As}(\mathrm{III})$ was $17.27 \%$. Following microbial enhanced pretreatment, the amount of lime required and waste residues generated for AMD neutralization decreased by $75.00 \%$ and $85.25 \%$, respectively. This result supports the application of microbial enhancement-lime neutralization passive treatment technology for AMD.

\section{Introduction}

Sulfide minerals in spent ore and mine tailings will oxidize when exposed to air and moisture during or after the processes of mining and beneficiation. Therefore, acid mine drainage (AMD) is typically characterized by high acidity $(\mathrm{pH}<5.0){ }^{1}$ Because of the sulfide minerals that contain heavy metals $(\mathrm{Cr}$, $\mathrm{Cu}, \mathrm{Cd}, \mathrm{Ni}$, etc.) or metalloids (As, $\mathrm{Hg}$, etc.) dissolved in acidic solution, AMD typically contains elevated concentrations of $\mathrm{Fe}$ $\left(\mathrm{Fe}^{2+}\right.$ and $\left.\mathrm{Fe}^{3+}\right), \mathrm{SO}_{4}{ }^{2-}$, and toxic metals, posing a threat to the environment and human health., ${ }^{2,3}$ AMD is typically treated using active and passive methods. ${ }^{4}$ Active treatment methods include lime neutralization, sulfide precipitation, and reduction-oxidation (redox), resulting in the precipitation of toxic metals. Passive treatment methods use natural geochemical and biochemical techniques to remove pollutants from wastewater with minimum investment and maintenance costs. Examples of active methods include aerobic/anaerobic wetlands, anoxic limestone drains, and permeable reactive

${ }^{a}$ Department of Environmental Engineering, School of Information and Safety Engineering, Zhongnan University of Economics and Law, Wuhan 430073, China. E-mail: syw1984888@sina.com; Fax:+8627 88385169; Tel: +862788385169

${ }^{b}$ Department of Environmental Engineering, College of Resources and Environmental Sciences, Nanjing Agricultural University, Nanjing 210095, China treatment zones (PRTZs). ${ }^{5}$ At present, lime neutralization is widely adopted owing to its convenience and speed and it can raise the $\mathrm{pH}$ level and remove $\mathrm{Fe}$ and $\mathrm{SO}_{4}{ }^{2-}$ from the AMD system through the formation of $\mathrm{Fe}(\mathrm{OH})_{3}, \mathrm{Fe}(\mathrm{OH})_{2}$, and $\mathrm{CaSO}_{4}{ }^{6}{ }^{6}$ However, higher operating costs and the difficulty of dewatering the waste residue are serious disadvantages of their application. ${ }^{7-9}$ Therefore, developing an effective and feasible AMD pretreatment method prior to lime neutralization has become an increasingly urgent issue.

Solubility products show that $\mathrm{Fe}^{2+}$ can only be precipitated as $\mathrm{Fe}(\mathrm{OH})_{2}$ under highly basic conditions, while $\mathrm{Fe}^{3+}$ can form $\mathrm{Fe}(\mathrm{OH})_{3}$ at $\mathrm{pH} 3-4$. Therefore, rapid conversion of $\mathrm{Fe}^{2+}$ into $\mathrm{Fe}^{3+}$ is essential for AMD pretreatment via the lime neutralization method. However, abiotic oxidation of $\mathrm{Fe}^{2+}$ by aeration is very slow at $\mathrm{pH}$ below 4.0. ${ }^{10}$ The abiotic oxidation efficiency of $\mathrm{Fe}^{2+}$ reaches $3 \%$ after $72 \mathrm{~h}$ in modified $9 \mathrm{~K}$ liquid medium with an initial $\mathrm{pH}$ of 2.5. ${ }^{11}$ Therefore, improving $\mathrm{Fe}^{2+}$ oxidation under low $\mathrm{pH}$ is a significant problem in AMD treatment. Acidithiobacillus ferrooxidans (A. ferrooxidans), one of the most common acidophilic Fe-oxidizing microorganisms, can efficiently catalyze the conversion of $\mathrm{Fe}^{2+}$ into $\mathrm{Fe}^{3+}$ without the excessive use of an AMD neutralizer and the generation of a highly alkaline effluent. ${ }^{12}$ Song et al. found that $8.96 \mathrm{~g} \mathrm{~L}^{-1}$ of $\mathrm{Fe}^{2+}$ could be completely bio-oxidized within $24 \mathrm{~h}$ when the density of $A$. ferrooxidans exceeded $5 \times 10^{7} \mathrm{UFC} \mathrm{mL}^{-1}$ in $9 \mathrm{~K}$ 
liquid medium with an initial $\mathrm{pH}$ of $2.5-3.0 .^{13}$ Further, the process of $\mathrm{Fe}^{2+}$ oxidation by $A$. ferrooxidans in the acidic sulfate environment is often accompanied by the hydrolysis of $\mathrm{Fe}^{3+}$ that generates iron oxyhydroxysulfate minerals, such as schwertmannite and jarosite. ${ }^{\mathbf{1 4}}$ Eqn (1)-(3) present the schwertmannite and jarosite formation:

$$
\begin{gathered}
4 \mathrm{Fe}^{2+}+\mathrm{O}_{2}+4 \mathrm{H}^{+} \rightarrow 4 \mathrm{Fe}^{3+}+2 \mathrm{H}_{2} \mathrm{O} \\
8 \mathrm{Fe}^{3+}+14 \mathrm{H}_{2} \mathrm{O}+\mathrm{SO}_{4}{ }^{2-} \rightarrow \\
\mathrm{Fe}_{8} \mathrm{O}_{8}(\mathrm{OH})_{6} \mathrm{SO}_{4}(\text { schwertmannite })+22 \mathrm{H}^{+} \\
\mathrm{M}^{+}+3 \mathrm{Fe}^{3+}+2 \mathrm{SO}_{4}{ }^{2-}+6 \mathrm{H}_{2} \mathrm{O} \rightarrow \\
\mathrm{MFe}_{3}\left(\mathrm{SO}_{4}\right)_{2}(\mathrm{OH})_{6} \text { (jarosite) }+6 \mathrm{H}^{+}
\end{gathered}
$$

$\mathrm{M}^{+}$represents $\mathrm{K}^{+}, \mathrm{NH}_{4}{ }^{+}$, and $\mathrm{Na}^{+}{ }^{\mathbf{1 2}}$

Schwertmannite and jarosite are commonly found in acidic, Fe and $\mathrm{SO}_{4}{ }^{2-}$-rich environments. ${ }^{15}$ Previous studies confirmed that these minerals are ideal adsorbents with relatively strong adsorption or co-precipitation effects on heavy metals. ${ }^{16-18}$ Liao et al. observed that As(III) adsorption by schwertmannite was enhanced with the increase in the solution $\mathrm{pH}$ from 3.0 to 9.0 and the maximum adsorption capacity was $113.9 \mathrm{mg} \mathrm{g}^{-1}$ at $\mathrm{pH}$ 7.5. ${ }^{19}$ Jarosite is also an efficient mineralogical control on aqueous concentrations of As in As-contaminated water. ${ }^{20}$ In addition, iron oxyhydroxysulfate minerals possess significant settling characteristics compared to $\mathrm{Fe}(\mathrm{OH})_{3} \cdot{ }^{21}$ Therefore, AMD pre-processing using $A$. ferrooxidans, followed by the treatment of the effluent via the lime neutralization method has a significant potential in the treatment of AMD.

In recent years, many types of reactors operating under both batch and continuous regimes have been studied to improve the bio-oxidation rate of $\mathrm{Fe}^{2+} .^{22,23}$ However, a continuously operating system will dilute and washout the Fe-oxidizing microorganisms, restricting its commercial application. Therefore, using immobilized cells would be a superior approach to improve the rate of oxidation and achieve high cell concentrations inside the reactor. ${ }^{24}$ Long et al. investigated the kinetics of continuous $\mathrm{Fe}^{2+}$ oxidation by PVA-cryogel-immobilized A. ferrooxidans in a $365 \mathrm{~mL}$ packed-bed bioreactor. A maximum $\mathrm{Fe}^{2+}$ oxidation rate of $1.89 \mathrm{~g} \mathrm{~L}^{-1} \mathrm{~h}^{-1}$ was achieved when the dilution rate was greater than $0.38 \mathrm{~h}^{-1} \cdot{ }^{25}$ The feasibility of jarosite as a support for $A$. ferrooxidans immobilization was also investigated in the present work. ${ }^{26}$ Wang et al. reported that jarosite as a microbial carrier can maintain a high concentration of $A$. ferrooxidans cells to improve $\mathrm{Fe}^{2+}$ oxidation and promote the precipitation of $\mathrm{Fe}^{3+}$ by simultaneously acting as a jarosite seed. ${ }^{27}$ The presence of seed materials can provide a solid surface, favors the jarosite surface creation, and promotes the rate of jarosite precipitation. ${ }^{28,29}$ Thus, the newlyformed jarosite can be retained or recycled to the reactor system as a new biomass carrier and a seed crystal to strengthen the process, forming a self-reinforcing positive feedback loop, whereas the excess can easily be removed, owing to its favorable settling properties. The rapid oxidation of $\mathrm{Fe}^{2+}$ and precipitation (iron oxyhydroxysulfate mineral formation) of $\mathrm{Fe}^{3+}$ by A. ferrooxidans can play multiple roles in improving the AMD treatment. The optimum amount of lime for $\mathrm{Fe}^{2+}$ oxidation and total Fe precipitation for iron oxyhydroxysulfate mineral formation during $\mathrm{Fe}^{2+}$ oxidation in AMD systems in the presence of $A$. ferrooxidans have been investigated under laboratory conditions. ${ }^{11}$ However, a semi-pilot study of AMD bioaugmentation pretreatment prior to lime neutralization in a continuously operating system has not been reported to date.

Mining activities typically take place in mountainous or hilly areas. The use of conventional sewage treatment techniques in these areas will inevitably incur high construction, operation, and management costs, as well as disrupt the original topography and ecological balance. AMD usually flows from the upper reaches of a mine to the downstream along a longer ditch. The plug-flow characteristics of in situ mining wastewater ditches could be integrated with microbial enhancement. Given that A. ferrooxidans is an aerobic bacterium, the continuous supply of $\mathrm{O}_{2}$ is essential for the biosynthesis of iron oxyhydroxysulfate minerals. ${ }^{30}$ In a plug-flow system, $\mathrm{O}_{2}$ required by $A$. ferrooxidans can be obtained through the drop aeration of AMD in the ditch. Such conditions are conducive to $\mathrm{Fe}^{2+}$ bio-oxidation and $\mathrm{Fe}^{3+}$ hydrolysis in AMD systems in the presence of A. ferrooxidans. Hydraulic residence time (HRT, determined by flow velocity) plays an important role in the overall activity of microorganisms. A very short HRT may not allow adequate time for bacterial activity in $\mathrm{Fe}^{2+}$ bio-oxidation and $\mathrm{Fe}^{3+}$ hydrolysis or may result in biomass being washed out of the system..$^{31}$ On the contrary, a very long HRT may reduce the processing capacity and result in high costs.

In the present work, a microbial (A. ferrooxidans) enhanced plug-flow ditch system was designed. The main purpose of this study was to evaluate the operational stability of the system under different HRTs and investigate the $\mathrm{Fe}^{2+}$ bio-oxidation efficiency, total Fe precipitation rate, dissolved $\mathrm{O}_{2}$ concentration, and removal efficiencies of As(III) in AMD. Furthermore, we compared the microbial enhancement-lime neutralization method with the original lime neutralization method to provide evidence to support the application of the new microbial enhancement-lime neutralization passive technique for AMD treatment. The outcomes of this study will provide the critical parameters for the engineering treatment of AMD.

\section{Materials and methods}

\subsection{Preparation of synthetic AMD}

Synthetic AMD, containing different concentrations of elements, was prepared as follows: $\mathrm{As}_{2} \mathrm{O}_{3}$ was used to prepare $100 \mathrm{mg} \mathrm{L}{ }^{-1}$ stock solutions of As(III). Then, the stock solutions of $\mathrm{FeSO}_{4} \cdot 7 \mathrm{H}_{2} \mathrm{O}$ and $\mathrm{As}(\mathrm{III})$ were added into a $1 / 5 \times$ modified $9 \mathrm{~K}$ broth medium to obtain $5 \mathrm{~g} \mathrm{~L}^{-1} \mathrm{Fe}^{2+}$ and $1 \mathrm{mg} \mathrm{L^{-1 }} \mathrm{As}(\mathrm{III})$, respectively. Finally, the $\mathrm{pH}$ of these final solutions was adjusted to 2.50 using $1 \mathrm{~mol} \mathrm{~L}^{-1} \mathrm{H}_{2} \mathrm{SO}_{4}$.

\subsection{Preparation of $A$. ferrooxidans cell suspensions}

A. ferrooxidans LX5 (CGMCC no. 0727), obtained from the China General Microbiological Culture Collection Center (CGMCC), was grown in a $9 \mathrm{~K}$ medium containing the following analytical grade salts: $3.00 \mathrm{~g}\left(\mathrm{NH}_{4}\right)_{2} \mathrm{SO}_{4}, 0.10 \mathrm{~g} \mathrm{KCl}, 0.50 \mathrm{~g} \mathrm{~K} \mathrm{HPO}_{4}, 0.50 \mathrm{~g}$ 
$\mathrm{MgSO}_{4} \cdot 7 \mathrm{H}_{2} \mathrm{O}, 0.01 \mathrm{~g} \mathrm{Ca}\left(\mathrm{NO}_{3}\right)_{2}$, and $44.48 \mathrm{~g} \mathrm{FeSO} \cdot \cdot 7 \mathrm{H}_{2} \mathrm{O}$ in $1 \mathrm{~L}$ deionized water. The $\mathrm{pH}$ value was adjusted to 2.50 using $\mathrm{H}_{2} \mathrm{SO}_{4}$. The $\mathrm{FeSO}_{4}$ solution was filtered, sterilized, and subsequently added to the remaining autoclaved $\left(121^{\circ} \mathrm{C}\right.$ for $\left.15 \mathrm{~min}\right)$ medium components. Cultures of $A$. ferrooxidans were incubated in $500 \mathrm{~mL}$ Erlenmeyer flasks, each containing $225 \mathrm{~mL}$ of $9 \mathrm{~K}$ medium and $10 \%(\mathrm{v} / \mathrm{v})$ inoculum at $28{ }^{\circ} \mathrm{C}$, placed on a rotary shaker at $180 \mathrm{rpm}$. The cells were harvested during the late logarithmic growth phase (72 h after inoculation). The cultures were initially filtered (Whatman no. 4 filter paper) to remove the precipitate. Subsequently, the filtrates were centrifuged at $10000 \times g$ for $10 \mathrm{~min}$ at $4{ }^{\circ} \mathrm{C}$ to precipitate the bacterial cells and the supernatant was discarded. After twofold washing with a dilute $\mathrm{H}_{2} \mathrm{SO}_{4}$ solution ( $\mathrm{pH}$ 1.50), the cells were resuspended in a dilute $\mathrm{H}_{2} \mathrm{SO}_{4}$ solution ( $\mathrm{pH} 2.50$ ). The A. ferrooxidans cell

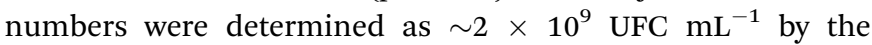
double-layer plate method. ${ }^{32}$

\subsection{Construction of the microbial enhanced plug-flow ditch system}

The new plug-flow ditch system was composed of an $800 \mathrm{~mm} \times$ $570 \mathrm{~mm} \times 505 \mathrm{~mm}$ (length $\times$ width $\times$ height $)$ transit box, consisting of six vertical ditches (zones 1-6) separated by PVC baffles. Three bubble aeration heads were installed at the bottom of each ditch to simulate the oxygenation process of drop aeration in a natural ditch environment. One $10 \mathrm{~mm} \times$ $10 \mathrm{~mm}$ diversion hole was fixed at the bottom of each PVC baffle between two ditches, while a $400 \mathrm{~mm}$ high effluent outlet was fixed at the end of zone 6 . Hence, the effective volume of the ditch system was approximately $180 \mathrm{~L}$. The plug-flow direction of the AMD is shown in Fig. 1.

\subsection{Microbial enhanced plug-flow assay of AMD}

The concentrated dormant cells of $A$. ferrooxidans were diluted and evenly mixed by stirring them with deionized water to

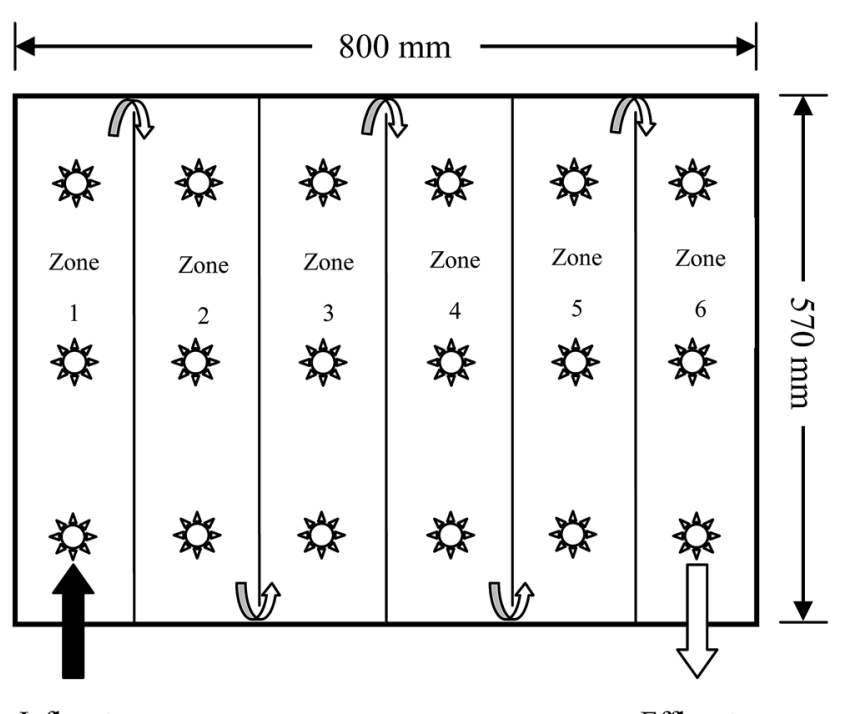

Influent

Effluent

Fig. 1 Configuration sketch map of AMD flow in the plug-flow ditch system. achieve a cell density of $\sim 5 \times 10^{7}$ UFC $\mathrm{mL}^{-1}$. The resulting $180 \mathrm{~L}$ solution containing diluted bacteria was evenly distributed between the zones of the ditch system. The concentration of dissolved $\mathrm{O}_{2}$ in each zone of the system was adjusted to $8 \mathrm{mg} \mathrm{L}^{-1}$ using an oxygenation and aeration device.

The synthetic AMD was pumped continually at a flow velocity of $2.5 \mathrm{~L} \mathrm{~h}^{-1}$ into zone 1 , after which it was transferred to zones 2 , $3,4,5$, and 6 , prior to being discharged via the outlet. At that time, the HRT of the AMD was 3 days. The system was operated continually in this pattern for 10 days. Samples were collected daily from each zone to measure $\mathrm{pH}, \mathrm{Fe}^{2+}$, and $\mathrm{O}_{2}$ concentrations to assess the continuous stability of the plug-flow system. Moreover, residual concentrations of total $\mathrm{Fe}$ and $\mathrm{As}^{3+}$ in the effluent from zone 6 were measured to calculate their respective removal rates. The abovementioned steps were repeated with HRTs of 2 days and 1 day to observe the operational stability of the plug-flow ditch system with varying HRTs and to examine the actual effectiveness of the microbial enhancement-lime neutralization passive technique for AMD treatment. Given that the abiotic oxidation of $\mathrm{Fe}^{2+}$ is hardly initiated below $\mathrm{pH}$ 4.0, a control group without the inoculation of $A$. ferrooxidans was not designed in this study. All experiments were performed in triplicate.

\subsection{Analytical procedures}

The solution $\mathrm{pH}$ was measured using a digital $\mathrm{pH}$ meter with a resolution of $0.01 \mathrm{pH}$ unit (pHS-3C, Shanghai INESA Scientific Instrument Co., Ltd). The dissolved $\mathrm{O}_{2}$ concentrations were measured using a Thermo DO analyzer with a resolution of $0.01 \mathrm{mg} \mathrm{L}^{-1}$ (ECDO270042). $\mathrm{Fe}^{2+}$ and total $\mathrm{Fe}$ concentrations were determined using the 1,10-phenanthroline method..$^{33}$ The mineral phase and the morphology of the precipitate were determined by X-ray diffraction (XRD, Bruker D8A25) using $\mathrm{CuK} \alpha$ radiation $(40 \mathrm{kV}, 40 \mathrm{~mA})$ and field emission scanning electron microscopy (SU8010, Hitachi High-Technologies Corporation, Tokyo, Japan). ${ }^{34}$ The chemical analysis of As species was performed using X-ray photoelectron spectroscopy (XPS, VG-Multilab 2000). The XPS spectra were obtained with a monochromated $\mathrm{Al}-\mathrm{K} \alpha \mathrm{X}$-ray source, with an analyzer pass energy of $25 \mathrm{eV}$ and a step size of $0.05 \mathrm{eV} .{ }^{35}$ Total As concentrations in the solution was analyzed through atomic fluorescence spectroscopy (AFS-9730, Beijing Haiguang Instrument Co., Ltd) with a detection limit of $0.01 \mu \mathrm{g} \mathrm{L} \mathrm{L}^{-1} \cdot{ }^{36}$ Experimental data were analyzed using SAS 9.2 software. The data shown in the figures are presented as the mean values with standard deviations to show their reproducibility and reliability.

\section{Results and discussion}

\subsection{Variations in $\mathbf{p H}$ with HRT in the plug-flow ditch system}

Fig. 2 shows the changes in $\mathrm{pH}$ with time in each zone of the microbial enhanced plug-flow ditch system under different HRTs. With an adequate supply of nutrients (e.g., N, P, K), A. ferrooxidans utilizes $\mathrm{Fe}^{2+}$ in AMD as an energy source for its metabolism. This reaction is accompanied by the hydrolysis of $\mathrm{Fe}^{3+}$ into iron oxyhydroxysulfate minerals. ${ }^{12-14}$ 


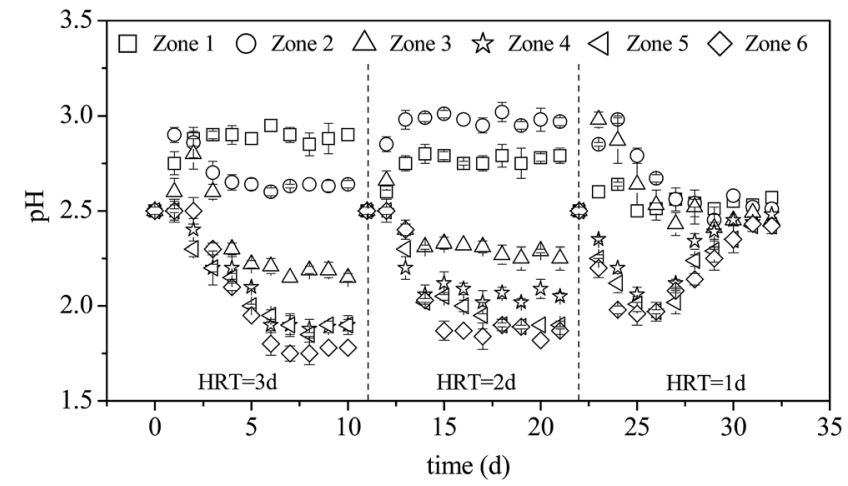

Fig. 2 Variations in $\mathrm{pH}$ with HRT during the treatment of AMD in the plug-flow ditch system (initial pH was 2.50).

Eqn (1)-(3) clearly show that the oxidation of $\mathrm{Fe}^{2+}$, mediated by $A$. ferrooxidans to form minerals, involves a two-step acid effect process. The first step is the acid-depleting bio-oxidation of $\mathrm{Fe}^{2+}$, while the second step is the acid-producing hydrolysis of $\mathrm{Fe}^{3+}$ to form minerals. Hence, the status and stability of the system under different HRTs can be determined via $\mathrm{pH}$ changes in each zone. When the HRT was 3 days, the $\mathrm{pH}$ of zone 1 increased from 2.50 to 2.88 and remained relatively stable after the system had been in operation for 2 days; the $\mathrm{pH}$ of zones 2 and 3 increased at the beginning and then decreased gradually over time; the $\mathrm{pH}$ of zones 4-6 decreased gradually with the prolongation of microbial enhancement and stabilized on the sixth day at values $2.10,2.00$, and 1.95 , respectively. eqn (1) and (2) show that bio-oxidation of $\mathrm{Fe}^{2+}$ is the dominant (aciddepleting) process in zone 1 , while in zones $2-6, \mathrm{Fe}^{3+}$ was continually hydrolyzed to form minerals (acid-producing) with continuous hydraulic action. There were differences in the degree of pH changes in zone 2 between HRTs of 2 and 3 days. When the system HRT was shortened from 3 to 2 days, the main region where $A$. ferrooxidans oxidation of $\mathrm{Fe}^{2+}$ took place also changed, meaning that the $\mathrm{pH}$ in zone 2 was higher than that in zone 1 . On the other hand, the plug-flow ditch system was only operated for four days and the $\mathrm{pH}$ of each zone began to gradually return to the initial value at the HRT of 1 day. Previous research showed that $A$. ferrooxidans can be covered with or absorbed by iron oxyhydroxysulfate minerals during the biosynthesis of iron oxyhydroxysulfate minerals by A. ferrooxidans, which can prevent the washout of A. ferrooxidans cells in a continuously operating system..$^{26,27}$ However, Song et al. reported that the total Fe precipitation efficiency (iron oxyhydroxysulfate mineral formation) was only $\sim 9 \%$ at $24 \mathrm{~h}$ when the density of A. ferrooxidans exceeded $5 \times 10^{7} \mathrm{UFC} \mathrm{mL}^{-1}$ in the $9 \mathrm{~K}$ liquid medium with the initial $\mathrm{pH}$ of $2.50 . .^{13}$ The results $($ HRT $=1 \mathrm{~d})$ indirectly reflect the gradual decline in the cell density of $A$. ferrooxidans suspended in the system as a result of the continuous discharge of the effluent that eventually led to the collapse of the system. To confirm this discovery, the density of A. ferrooxidans in the liquid phase of zone 6 was determined after the plug-flow ditch system was in operation for ten days when HRT was one day. The cell number of A. ferrooxidans significantly $(P<0.05)$ decreased from the initial value of $5 \times$ $10^{7} \mathrm{UFC} \mathrm{mL}^{-1}$ to $3 \times 10^{3} \mathrm{UFC} \mathrm{mL}^{-1}$ in the liquid phase.
3.2. Variations in $\mathrm{Fe}^{2+}$ and $\mathrm{O}_{2}$ concentrations with HRT in the plug-flow ditch system

The oxidation of $\mathrm{Fe}^{2+}$ to $\mathrm{Fe}^{3+}$ is required prior to lime neutralization because $\mathrm{Fe}^{3+}$ could precipitate at a much lower $\mathrm{pH}$ than $\mathrm{Fe}^{2+} .{ }^{27}$ Therefore, improving the efficiency of $\mathrm{Fe}^{2+}$ oxidation is a key regulatory step in AMD treatment. When HRT was 3 days, $\mathrm{Fe}^{2+}$ concentrations in zones 1-3 gradually increased under continuous AMD influx and stabilized on the sixth day at 4.61, 3.45 , and $1.01 \mathrm{~g} \mathrm{~L}^{-1}$ (equivalent to $\mathrm{Fe}^{2+}$ oxidation rates of $7.80 \%$, $31.0 \%$ and $79.8 \%$ ), respectively (Fig. 3). The results showed that A. ferrooxidans began to exploit the energy source in zone 1 with increasing utilization levels as the influent flowed in continually and $5 \mathrm{~g} \mathrm{~L}^{-1}$ of Fe$e^{2+}$ in AMD was completely oxidized by $A$. ferrooxidans when the influent reached zone 4 . When HRT was 2 days, the utilization rate of $\mathrm{Fe}^{2+}$ by $A$. ferrooxidans in the same zone was lower than that under an HRT of 3 days. However, the $\mathrm{Fe}^{2+}$ concentration in each zone showed an increasing trend as HRT was shortened to 1 day, which was consistent with the change in $\mathrm{pH}$, indicating that $A$. ferrooxidans had an extremely low $\mathrm{Fe}^{2+}$ utilization rate. Thus, the entire system rapidly became imbalanced.

The trends in $\mathrm{pH}$ and $\mathrm{Fe}^{2+}$ concentrations show that the system can be easily stabilized under a longer HRT. In practical applications, a shorter HRT is generally expected to achieve a higher treatment capacity. However, the metabolism, growth, and reproductive activity of $A$. ferrooxidans are the key factors that affect the operational stability of the system and accelerate the oxidation of $\mathrm{Fe}^{2+}$ to form minerals, limiting the possibility of continually shortening the HRT. The system will be irreversibly disrupted and become imbalanced because of the greater hydraulic load if HRT drops below its lowest critical value. ${ }^{37}$ Given that $\mathrm{Fe}^{2+}$ in the effluent of the system could be completely oxidized when the HRT was 2 days, the recommended optimum HRT for the plug-flow ditch system was 2 days.

A. ferrooxidans is an obligate aerobe that requires an adequate supply of $\mathrm{O}_{2}$ for growth. $\mathrm{O}_{2}$ serves as the only electron acceptor for oxidizing $\mathrm{Fe}^{2+} \cdot{ }^{38,39}$ When the HRT was 3 and 2 days, $\mathrm{O}_{2}$ concentrations in zones 1-6 initially decreased and then increased (Fig. 4). Moreover, zones 3 and 4 had the lowest $\mathrm{O}_{2}$ concentrations ( $2.95 \mathrm{mg} \mathrm{L}^{-1}$ and $3.34 \mathrm{mg} \mathrm{L}^{-1}$, respectively). The

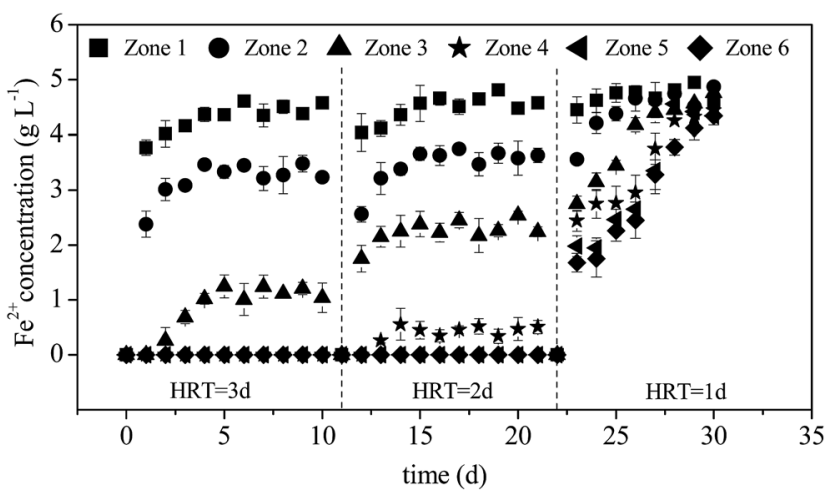

Fig. 3 Variations in $\mathrm{Fe}^{2+}$ concentrations with HRT during the treatment of AMD in the plug-flow ditch system (initial Fe ${ }^{2+}$ concentration was $5 \mathrm{~g} \mathrm{~L}^{-1}$ ). 


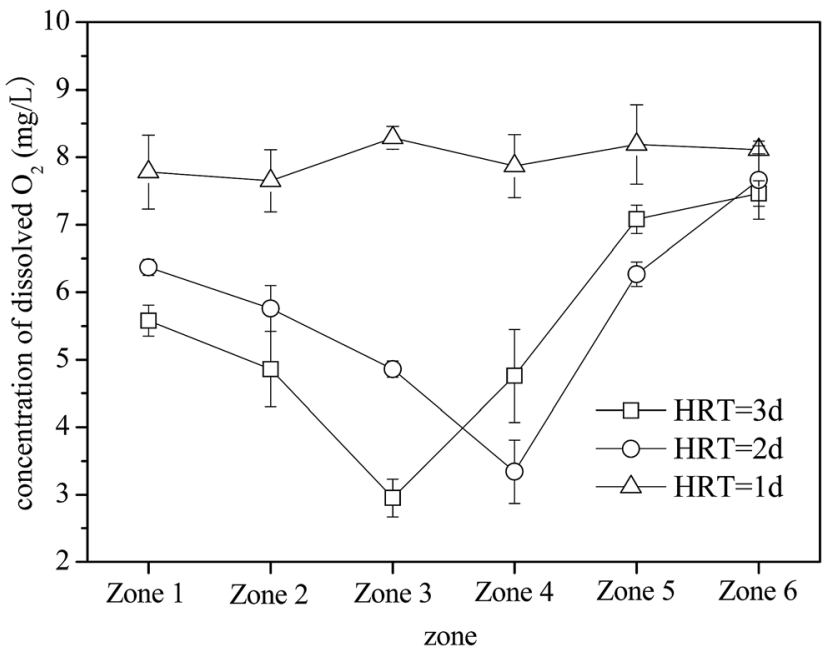

Fig. 4 Variations in $\mathrm{O}_{2}$ concentrations with HRT when the plug-flow ditch system is stable (initial $\mathrm{O}_{2}$ concentration was $8 \mathrm{mg} \mathrm{L}^{-1}$ ).

bio-oxidation rate of $\mathrm{Fe}^{2+}$ affected the changes in $\mathrm{O}_{2}$ concentrations in the plug-flow ditch system (Fig. 3). When the system was stable, the oxidation rates of $\mathrm{Fe}^{2+}$ in zones 1-6 were 7.80, $31.0,79.8,100,100$, and $100 \%$ (the net oxidation rates of $\mathrm{Fe}^{2+}$ were $7.80,23.2,48.8,20.2,0$, and $0 \%$ ) and the corresponding $\mathrm{O}_{2}$ concentrations were $5.58,4.86,2.95,4.76,7.08$, and $7.46 \mathrm{mg} \mathrm{L}^{-1}$, respectively, at the HRT of 3 days. After $\mathrm{Fe}^{2+}$ was completely oxidized, the $\mathrm{O}_{2}$ concentration in the solution increased rapidly and almost returned to the initial value. Statistical analysis of the results revealed that all the treatment groups significantly $(P<0.05)$. Therefore, the status of $\mathrm{Fe}^{2+}$ biooxidation by $A$. ferrooxidans can be evaluated using the $\mathrm{O}_{2}$ concentration in each zone of the system. However, because of the decrease in the A. ferrooxidans density at the HRT of 1 day due to the imbalanced system, $A$. ferrooxidans had a relatively weak capacity for $\mathrm{Fe}^{2+}$ oxidation. Hence, the $\mathrm{O}_{2}$ concentration in each zone was basically maintained at the initial aeration level. Many investigations indicated that $\mathrm{O}_{2}$ supply was only essential in the period of $\mathrm{Fe}^{2+}$ oxidation but was not required during the $\mathrm{Fe}^{3+}$ precipitation reaction. ${ }^{\mathbf{4 0 4 1}}$ This study suggests that $\mathrm{O}_{2}$ supply has an important function in the bio-oxidation of $\mathrm{Fe}^{2+}$; however, its function in the formation of iron oxyhydroxysulfate minerals can be neglected because the energy released from the oxidation of $\mathrm{Fe}^{2+}$ can be used for the subsequent hydrolysis reaction of $\mathrm{Fe}^{3+} \cdot{ }^{\mathbf{4 2 , 4 3}}$ This advantage would considerably reduce the cost of the biosynthesis of iron oxyhydroxysulfate minerals because the aeration operation can be eliminated in the $\mathrm{Fe}^{3+}$ hydrolysis process.

\subsection{Variations in the removal rate of total Fe and heavy metals with HRT when the plug-flow ditch system is stable}

During $\mathrm{Fe}^{2+}$ oxidation process by A. ferrooxidans, iron oxyhydroxysulfate minerals are generated because of the facilitation of subsequent $\mathrm{Fe}^{3+}$ hydrolysis. ${ }^{\mathbf{1 2 - 1 4}}$ Fe removed from AMD by the formation of iron oxyhydroxysulfate minerals have certain advantages over $\mathrm{Fe}(\mathrm{OH})_{3}$ because these minerals have significant settling characteristics that aid the dewaterability of neutralized precipitates after AMD treatment by lime neutralization. ${ }^{21}$ Fig. 5 shows that total Fe precipitation rates in the simulated AMD exceeded $60 \%$ in zones 1-6 of the system when HRT was 3 days. The total Fe precipitation rate in the effluent from zone 6 decreased after the HRT was shortened to 2 days, even though $\mathrm{Fe}^{2+}$ had been completely oxidized by A. ferrooxidans in zone 5 (Fig. 3). However, more than $50 \%$ of $\mathrm{Fe}$ in the liquid phase still entered the solid phase, indicating that the capacity of $\mathrm{Fe}^{3+}$ hydrolysis to form minerals was basically unaffected. Conversely, the system was disrupted by hydraulic load and became imbalanced after shortening the HRT to 1 day, impeding $\mathrm{Fe}^{2+}$ oxidation by $A$. ferrooxidans and $\mathrm{Fe}^{3+}$ hydrolysis to form minerals. The results were consistent with those in previous reports that suggested that the $\mathrm{Fe}^{2+}$ oxidation rate, to a great extent, had a dominant function in the formation of iron oxyhydroxysulfate minerals. ${ }^{44-46}$

Previous studies confirmed that iron oxyhydroxysulfate minerals are ideal adsorbents with relatively strong adsorption or co-precipitation effects on heavy metals. ${ }^{16-18}$ The mechanism of As(III) adsorption on iron oxyhydroxysulfate minerals involves either ligand exchange between As(III) species and a hydroxyl group and sulfate or the formation of $\mathrm{As}(\mathrm{III})-\mathrm{Fe}(\mathrm{III})-\mathrm{SO}_{4}{ }^{2-}$ precipitates on the mineral surface. ${ }^{19}$ Owing to the influence of HRT on the total Fe precipitation rate in the synthetic AMD, a longer system HRT was more conducive to improving the removal rates of As(III) from AMD (Fig. 6). For HRTs of 3 and 2 days, the average removal rates of As(III) from the effluent in zone 6 were $21.58 \%$ and $17.27 \%$, respectively. The system showed a significantly lower removal rate of As(III), mainly because of the relatively higher effluent acidity $(\mathrm{pH}<2.0)$. Duquesne et al. noted that at such acidity, As(III) mainly exists in the form of electronically neutral $\mathrm{H}_{3} \mathrm{AsO}_{3}$ that rarely replaces $\mathrm{HSO}_{4}{ }^{-}$and $\mathrm{SO}_{4}{ }^{2-}$ groups in iron oxyhydroxysulfate minerals. ${ }^{47}$ XPS analysis revealed that $\mathrm{As}(\mathrm{III})$ in a solution adsorbed by minerals was in the form of $\mathrm{As}_{2} \mathrm{O}_{3}$ (Fig. 7) because the drying of iron oxyhydroxysulfate minerals caused the loss of crystalline water in $\mathrm{H}_{3} \mathrm{AsO}_{3}$ and resulted in the formation of $\mathrm{As}_{2} \mathrm{O}_{3}$.

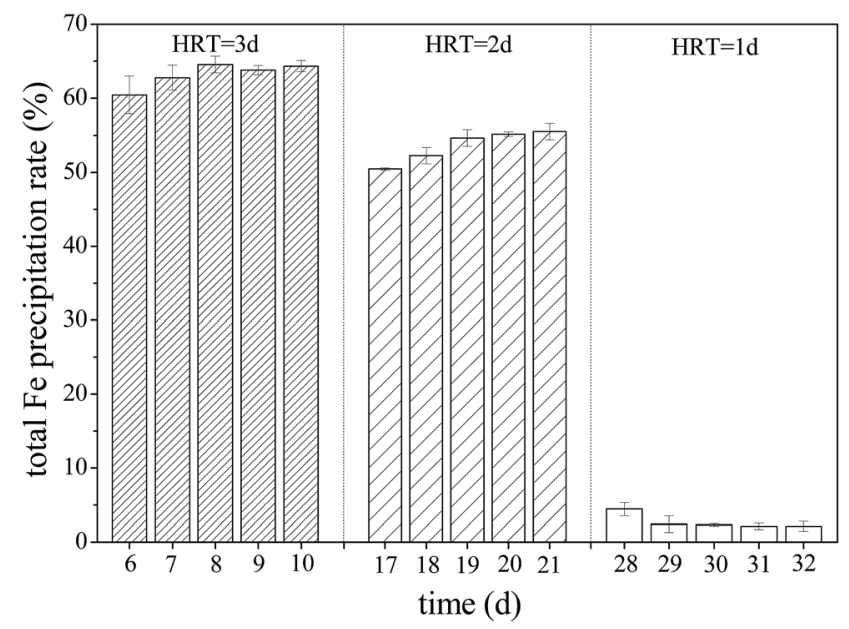

Fig. 5 Variations in total Fe precipitation rate with HRT when the plugflow ditch system is stable (initial total Fe concentration was $5 \mathrm{~g} \mathrm{~L}^{-1}$ ). 


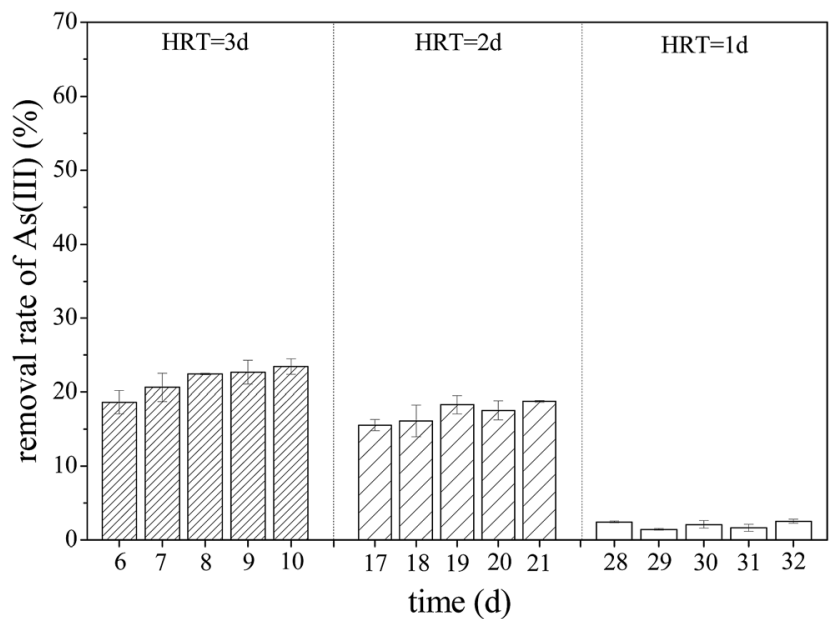

Fig. 6 Variations in the removal rate of As(III) with HRT when the plugflow ditch system is stable (initial As(III) concentration was $1 \mathrm{mg} \mathrm{L}^{-1}$ ).

3.4. The structural characteristics of iron oxyhydroxysulfate minerals collected from the plug-flow ditch system under an HRT of 2 days

The X-ray diffractogram (XRD) pattern and scanning electron microscopy (SEM) image of iron oxyhydroxysulfate minerals harvested from zone 6 after the system ceased operation when the HRT was 2 days are shown in Fig. 8. Based on the comparisons with the Joint Committee on Power Diffraction Standards data files cards no. 22-0827 and no. 47-1775, the minerals are composed of schwertmannite and K-jarosite. ${ }^{48}$ Although the synthetic AMD contained $\mathrm{NH}_{4}{ }^{+}$and $\mathrm{Na}^{+}$, there was no detectable diffraction peak of $\mathrm{NH}_{4}$-jarosite or Na-jarosite. Studies by Gramp et al. and Bai et al. suggested that this is mainly caused by the differences in the ability of monovalent cations to form jarosite-like minerals in the following order: $\mathrm{K}^{+}$ $>\mathrm{NH}_{4}{ }^{+}>\mathrm{Na}^{+} \cdot{ }^{49,50}$ The SEM micrograph shows that the resulting minerals mainly consist of $0.5-2.0 \mu \mathrm{m}$ spherical particles with sparse aggregation structures in the interparticle space. Additionally, there was a minute amount of irregular fine particulate minerals attached to the surface of the spherical particles and the gaps between them.

\subsection{Neutralization effect of the system on the effluent under an HRT of 2 days}

Previous studies reported that $\mathrm{Fe}(\mathrm{OH})_{3}, \mathrm{Fe}(\mathrm{OH})_{2}$, and $\mathrm{CaSO}_{4}$ are the main precipitates formed when lime is added into the $\mathrm{Fe}$ and $\mathrm{SO}_{4}{ }^{2-}$-rich acidic environment. ${ }^{6}$ Fig. 9 shows that $2 \mathrm{~g} \mathrm{~L}^{-1}$ lime is sufficient to completely remove the remaining $2.2 \mathrm{~g} \mathrm{~L}^{-1}$ $\mathrm{Fe}^{3+}$ from the effluent and the $\mathrm{pH}$ of the effluent significantly $(P$ $<0.01$ ) increases from 1.87 to 4.82 . An increase in the amount of lime added (from 2 to $3 \mathrm{~g} \mathrm{~L}^{-1}$ ) could nearly neutralize the effluent $(\mathrm{pH}=6.35)$, producing $5.23 \mathrm{~g} \mathrm{~L}^{-1}$ precipitate due to
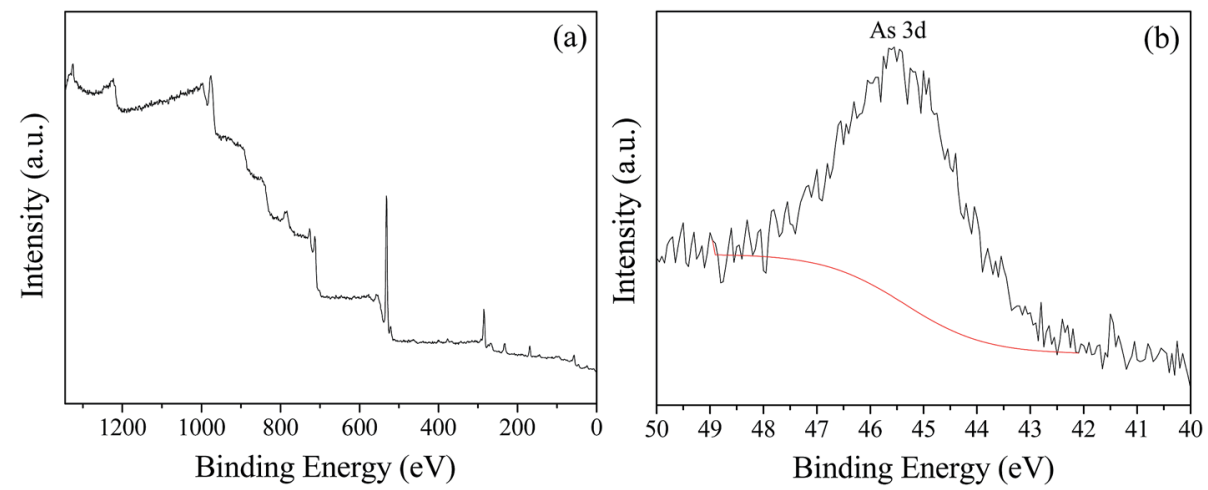

Fig. 7 XPS spectra of iron oxyhydroxysulfate minerals collected from zone 6 of the plug-flow ditch system (HRT $=2 \mathrm{~d}$ ).

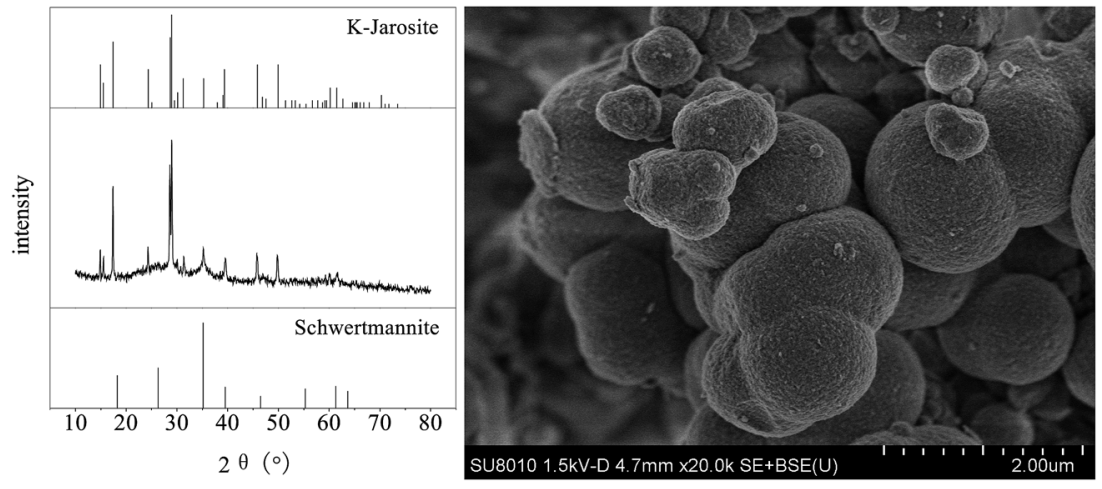

Fig. 8 XRD pattern and SEM image of iron oxyhydroxysulfate minerals collected from zone 6 of the plug-flow ditch system (HRT $=2$ d). 

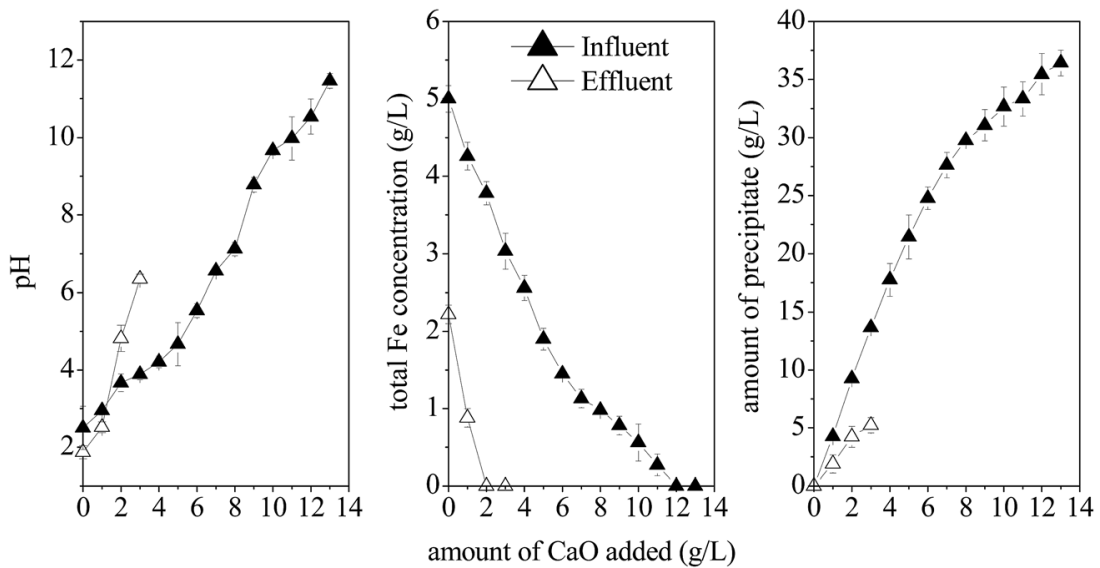

Fig. 9 Comparison of the neutralization efficiency between influent and effluent after simulated AMD treatment (HRT = $2 \mathrm{~d})$.

neutralization. The direct neutralization of the influent required up to $12 \mathrm{~g} \mathrm{~L}^{-1}$ of lime to precipitate $5 \mathrm{~g} \mathrm{~L}^{-1}$ of $\mathrm{Fe}^{2+}$, generating an effluent with a $\mathrm{pH}$ value of up to 10.54 and a precipitate of up to $35.45 \mathrm{~g} \mathrm{~L}^{-1}$. The pre-processing of synthetic AMD with the microbial enhanced plug-flow ditch system reduced the consumption of lime for neutralization and the amount of waste residues formed by $75.00 \%$ and $85.25 \%$ compared to that of the influent, respectively. In summary, the microbial enhancement-lime neutralization passive treatment technique can greatly reduce the Fe level in AMD, reduce the consumption of lime, and improve the neutralization efficiency. Further, the iron oxyhydroxysulfate minerals can be used to partially remove the toxic elements, thereby reducing pollution and harmful effects of AMD on the environment.

\section{Conclusions}

The oxidation of $\mathrm{Fe}^{2+}$ facilitated by $A$. ferrooxidans prior to lime neutralization has a significant potential for the treatment of AMD. A simulated AMD was subjected to the microbial enhanced pretreatment in a plug-flow ditch system with an effective volume of $180 \mathrm{~L}$.

(1) HRT had a strong influence on microbial activity during the treatment of AMD. For HRTs of 3 and 2 days, the system required 6 and 4 days, respectively, to stabilize. When HRT was 1 day, the system began to become imbalanced after 4 days of operation.

(2) For HRTs of 3 and 2 days, the average total Fe precipitation rates of the stabilized system were $63.18 \%$ and $53.62 \%$, respectively. The average removal rates of As(III) were $21.58 \%$ and $17.27 \%$, respectively. The precipitate was a mixture of schwertmannite and K-jarosite, and As(III) in solution adsorbed by minerals was in the form of $\mathrm{As}_{2} \mathrm{O}_{3}$. Considering the treatment capacity and the effects together, the selected optimum HRT for the plug-flow ditch system of the AMD is 2 days.

(3) At HRT of 2 days, after the pre-processing of synthetic AMD with the microbial enhanced plug-flow ditch system, the consumption of lime for neutralization and the amount of waste residues reduced by $75.00 \%$ and $85.25 \%$, respectively, compared to those of the influent. The outcomes of this study support the promotion and engineering applications of microbial enhancement-lime neutralization passive treatment technology for AMD. Future studies will focus on the selection of microbial immobilization carriers, the sedimentation and dewatering performance of neutralizing products, and the economic cost analysis of this technology.

\section{Conflicts of interest}

There are no conflicts to declare.

\section{Acknowledgements}

This work was supported by the National Natural Science Foundation of China (21637003), the Natural Science Foundation of Hubei Province, China (2016CFB289), and the Talent Introduction Foundation of Zhongnan University of Economics and Law (31541711302).

\section{References}

1 L. X. Zhou, Earth Sci. Front., 2008, 15, 74-82.

2 M. Vhahangwele, J. Water Process Eng., 2016, 10, 67-77.

3 Z. L. Wu, L. C. Zou, J. H. Chen, X. K. Lai and Y. G. Zhu, Int. J. Miner. Process., 2016, 149, 18-24.

4 D. B. Johnson and K. B. Hallberg, Sci. Total Environ., 2005, 338, 3-14.

5 P. L. Younger, S. A. Banwart and R. S. Hedin, Mine Water: Hydrology, Pollution, Remediation, Kluwer Academic Press, The Netherlands, 2002.

6 P. Herrera, H. Uchiyama, T. Lgarashi, K. Asakura, Y. Ochi, N. Iyatomi and S. Nagae, Miner. Eng., 2007, 20, 1255-1260.

7 Y. W. Song, M. Wang, J. R. Liang and L. X. Zhou, Hydrometallurgy, 2014, 143, 23-27.

8 W. C. Lee, S. W. Lee, S. T. Yun and P. K. Lee, J. Hazard. Mater., 2016, 301, 332-341.

9 K. Meschke, V. Herdegen, T. Aubel, E. Janneck and J. U. Repke, J. Environ. Chem. Eng., 2015, 4, 2848-2856. 
10 Y. Yang, Y. Li and Q. Y. Sun, Trans. Nonferrous Met. Soc. China, 2014, 24, 3332-3342.

11 F. W. Liu, J. Zhou, T. J. Jin, S. S. Zhang and L. L. Liu, Water Sci. Technol., 2016, 73, 1442-1453.

12 Y. W. Song, B. W. Zhao, M. B. Huo, C. H. Cui and L. X. Zhou, Environ. Sci., 2013, 34, 3264-3271.

13 Y. W. Song, H. R. Wang, J. R. Liang and L. X. Zhou, Acta Sci. Circumstantiae, 2016, 36, 3683-3690.

14 J. Zhu, M. Gan, D. Zhang and L. Chai, Mater. Sci. Eng., C, 2013, 33, 2679-2685.

15 J. M. Bigham, U. Schwertmann, S. J. Traina, R. L. Winland and M. Wolf, Geochem. Cosmochim. Acta, 1996, 60, 21112121.

16 S. L. Zhang, S. Y. Jia, B. Yu, Y. Liu and S. H. Wu, Chem. Geol., 2016, 420, 270-279.

17 M. Gan, S. G. Sun and Z. H. Zheng, Appl. Surf. Sci., 2015, 356, 986-997.

18 K. M. Mihone, F. Hana and R. Sanda, J. Geochem. Explor., 2015, 148, 161-168.

19 Y. H. Liao, J. R. Liang and L. X. Zhou, Chemosphere, 2011, 83, 295-301.

20 S. G. Johnston, E. D. Burton, A. F. Keene, B. P. Friedrich, A. Voegelin and M. G. Blackford, Chem. Geol., 2012, 334, 924.

21 P. Asokan, M. Saxena and S. R. Asolekar, J. Hazard. Mater., 2006, 137, 1589-1599.

22 M. Nemati, S. T. L. Harrison, G. S. Hansford and C. Webb, Biochem. Eng. J., 1998, 1, 171-191.

23 Z.-E. Long, Y. H. Huang, Z. L. Cai, W. Cong and F. Ouyang, Hydrometallurgy, 2004, 74, 181-187.

24 Z.-E. Long, Y. H. Huang, Z. L. Cai, W. Cong and F. Ouyang, Biotechnol. Lett., 2003, 25, 245-249.

25 Z.-E. Long, Y. H. Huang, Z. L. Cai, W. Cong and F. Ouyang, Process Biochem., 2004, 39, 2129-2133.

26 B. Escobar, E. Jedlicki, J. Wiertz and T. Vargas, Hydrometallurgy, 1996, 40, 1-10.

27 M. Wang and L. X. Zhou, Hydrometallurgy, 2012, 125-126, 152-156.

28 J. E. Dutrizac, Metall. Trans. B, 1983, 14, 531-539.

29 J. E. Dutrizac, Hydrometallurgy, 1996, 42, 293-312.

30 M. Gleisner, J. R. R. Herbert and P. C. F. Kockum, Chem. Geol., 2006, 225, 16-69.
31 C. M. Neculita, G. J. Zagury and B. Bussiere, J. Environ. Qual., 2007, 36, 1-16.

32 Y. H. Liao, L. X. Zhou, J. R. Liang and H. X. Xiong, Mater. Sci. Eng., C, 2009, 29, 211-215.

33 F. W. Liu, S. Y. Gao, M. Wang, Y. S. Bu, C. H. Cui and L. X. Zhou, China Environ. Sci., 2014, 34, 713-719.

34 F. W. Liu, S. Y. Gao, M. Wang, H. Y. Yu, C. H. Cui and L. X. Zhou, Acta Sci. Circumstantiae, 2015, 35, 476-483.

35 Q. W. Huang, D. W. Zeng, S. Q. Tian and C. S. Xie, Mater. Lett., 2012, 83, 76-79.

36 S. Houngaloune, T. Kawaai, N. Hiroyoshi and M. Ito, Hydrometallurgy, 2014, 147-148, 30-40.

37 C. M. Neculita, G. J. Zagury and B. Bussiere, Appl. Geochem., 2008, 23, 3442-3451.

38 J. T. Pronk, K. Liem, P. Bos and J. G. Kuenen, Appl. Environ. Microbiol., 1991, 57, 2063-2068.

39 N. Ohmura, K. Sasaki, N. Matsumoto and H. Saiki, J. Bacteriol., 2002, 184, 2081-2087.

40 Y. H. Liao, L. X. Zhou, S. Y. Bai, J. R. Liang and S. M. Wang, Appl. Geochem., 2009, 24, 1739-1746.

41 Q. J. Hou, D. Fang, J. R. Liang and L. X. Zhou, PLoS One, 2015, 10, 1-12, DOI: 10.1371/journal.pone.0120966.

42 J. Majzlan and A. Navrotsky, Geochim. Cosmochim. Acta, 2004, 68, 1049-1059.

43 A. Amouric, A. C. Brochier, D. B. Johnson, V. Bonnefoy and K. B. Hallberg, Microbiology, 2011, 157, 111-122, DOI: 10.1099/mic.0.0445370.

44 S. Huang and L. X. Zhou, Mater. Sci. Eng., C, 2012, 32, 916921.

45 A. Mahiroglu, E. T. Yel and M. F. Sevimli, J. Hazard. Mater., 2009, 166, 782-787, DOI: 10.1016/j.jhazmat.2008.11.119.

46 S. Y. Bai, J. R. Liang and L. X. Zhou, Acta Mineral. Sin., 2011, 31, 118-125.

47 K. Duquesne, S. Lebrun, C. Casiot and O. Bruneel, Appl. Environ. Microbiol., 2003, 69, 6165-6173.

48 JCPDS, Mineral Powder Diffraction Files, International Center for Diffraction Data, Swarthmore, Pennsylvania, 2002.

49 J. P. Gramp, F. S. Jones, J. M. Bigham and O. H. Tuovinen, Hydrometallurgy, 2008, 94, 29-33.

50 S. Y. Bai, Z. H. Xu, M. Wang, Y. H. Liao, J. R. Liang, C. C. Zheng and L. X. Zhou, Mater. Sci. Eng., C, 2012, 32, 2323-2329. 